\title{
Copper extraction from coarsely ground printed circuit boards using moderate thermophilic bacteria in a rotating-drum reactor
}

\author{
Michael L.M. Rodrigues ${ }^{\mathrm{a}, *}$, Versiane A. Leão ${ }^{\mathrm{a}}$, Otavio Gomes ${ }^{\mathrm{b}}$, Fanny Lambert ${ }^{\mathrm{c}}$, David Bastin ${ }^{\mathrm{c}}$, \\ Stoyan Gaydardzhiev ${ }^{\mathrm{c}}$ \\ a BioEHHydrometallurgy Laboratory, Department of Metallurgical and Materials Engineering, Universidade Federal de Ouro Preto, Campus Morro do Cruzeiro, Ouro Preto, MG \\ 35400-000, Brazil \\ ${ }^{\mathrm{b}}$ Centre for Mineral Technology - CETEM, Av Pedro Calmon, 900, 21941-908 Rio de Janeiro, Brazil \\ ${ }^{\mathrm{c}}$ Mineral Processing and Recycling, University of Liege, SartTilman, 4000 Liege, Belgium
}

\section{A R T I C L E I N F O}

\section{Article history:}

Received 18 December 2014

Accepted 1 April 2015

Available online 18 April 2015

\section{Keywords:}

Bioleaching

Copper

$\mathrm{PCB}$

Sulfobacillus thermosulfidooxidans

Rotating-drum reactor

\begin{abstract}
A B S T R A C T
The current work reports on a new approach for copper bioleaching from Printed Circuit Board (PCB) by moderate thermophiles in a rotating-drum reactor. Initially leaching of PCB was carried out in shake flasks to assess the effects of particle size $(-208 \mu \mathrm{m}+147 \mu \mathrm{m})$, ferrous iron concentration $(1.25-10.0 \mathrm{~g} / \mathrm{L})$ and $\mathrm{pH}(1.5-2.5)$ on copper leaching using mesophile and moderate thermophile microorganisms. Only at a relatively low solid content $(10.0 \mathrm{~g} / \mathrm{L})$ complete copper extraction was achieved from the particle size investigated. Conversely, high copper extractions were possible from coarse-ground PCB (20 mm-long) working with increased solids concentration (up to $25.0 \mathrm{~g} / \mathrm{L}$ ). Because there was as the faster leaching kinetics at $50^{\circ} \mathrm{C}$ Sulfobacillus thermosulfidooxidans was selected for experiments in a rotating-drum reactor with the coarser-sized PCB sheets. Under optimal conditions, copper extraction reached $85 \%$, in 8 days and microscopic observations by SEM-EDS of the on nonleached and leached material suggested that metal dissolution from the internal layers was restricted by the fact that metal surface was not entirely available and accessible for the solution in the case of the $20 \mathrm{~mm}$-size sheets.
\end{abstract}

(ㄷ) 2015 Elsevier Ltd. All rights reserved.

\section{Introduction}

Technological innovations have stimulated widespread utilization of electronic equipment, which has also resulted in a considerable increase in the generation of electronic waste (ewaste). Incineration and landfilling are often the ways to deal with electronic waste (Xiang et al., 2010), however such methods are increasingly being considered inappropriate because of their negative environmental impacts as shown by the recent studies (Brandl et al., 2001; Yang et al., 2009). Conversely, electronic wastes can also be viewed as alternative source of non-ferrous metals such as copper, nickel, and zinc as well as gold and silver (Lee and Pandey, 2012) and both pyrometallurgical and hydrometallurgical techniques can be applied for their recycling from e-wastes (Zhu et al., 2011).

Pyrometallurgy is particularly appropriate to recover copper and precious metals from some type of electronic waste such as

\footnotetext{
* Corresponding author.

E-mail addresses: mitchel.marques@yahoo.com.br (M.L.M. Rodrigues),versiane@ demet.em.ufop.br, versiane.ufop@gmail.com (V.A. Leão).
}

mobile phones, but the technique requires high grade feed and thus is not suitable for low grade e-wastes, including PCB. Moreover, pyrometallurgy is related to some environmental impacts such as greenhouse gases, formation of furans and dioxins and dust (Cui and Zhang, 2008; Ilyas et al., 2010; Zhu et al., 2013) and thus requires an off-gas treatment. In addition, rare earth metals, tantalum and gallium among other elements report to the slag phase because they are easily oxidized in the furnace atmosphere. Therefore, hydrometallurgy is considered an alternative because it is less complex and energy intensive and there is no generation of toxic gases (Tuncuk et al., 2012). Nevertheless, it is fair to admit that both approaches have their inconveniences and advantages making their combined use often the preferred scenario.

Bio-hydrometallurgy is a specialized branch of hydrometallurgy that utilizes microorganisms to solubilize metals and therefore is often viewed as eco-friendly process for the treatment of lowgrade ores and wastes (Poulin and Lawrence, 1996; Watling, 2006). Although, this is one of the most promising biotechnologies in the metallurgical sector, limited research has been reported regarding the bioleaching of $\mathrm{PCB}$ and a few examples are 
Table 1

Bioleaching of copper from PCB.

\begin{tabular}{|c|c|c|c|c|}
\hline $\begin{array}{l}\text { Specific type and source } \\
\text { of waste }\end{array}$ & Microorganisms & Leaching efficiency (\%) and conditions & Type of reactor & References \\
\hline РCB $-208 \mu \mathrm{m}+147 \mu \mathrm{m}$ & $\begin{array}{l}\text { Acidithiobacillus ferrooxidans and } \\
\text { Sulfobacillus } \\
\text { thermosulfidooxidans }\end{array}$ & $\begin{array}{l}94 \% \mathrm{Cu} \text { extraction at } 30^{\circ} \mathrm{C}(\mathrm{T} \text {. ferrooxidans }) \text { and } 99 \% \\
\text { at } 50{ }^{\circ} \mathrm{C}(\mathrm{S} \text {. thermosulfidooxidans }) \text { in } 6 \text { days with } \\
10 \mathrm{~g} / \mathrm{L} \mathrm{Fe}^{2+}, 10 \mathrm{~g} / \mathrm{L} \text { of } \mathrm{PCB} \text { and } \mathrm{pH} 1.75 ; 150 \mathrm{~min}^{-1}\end{array}$ & Shaking flask & Current work \\
\hline PCB 20 mm-long & S. thermosulfidooxidans & $\begin{array}{l}85 \% \mathrm{Cu} \text { extraction in } 8 \text { days at } 5 \mathrm{~g} / \mathrm{L} \mathrm{Fe}^{2+}, 25 \mathrm{~g} / \mathrm{L} \mathrm{PCB} \\
\text { and } \mathrm{pH} 1.75 \text {. Rotating-drum reactor at } 50{ }^{\circ} \mathrm{C} \text { and } \\
80 \mathrm{~min}^{-1}\end{array}$ & $\begin{array}{l}\text { Rotating-drum } \\
\text { reactor }\end{array}$ & Current work \\
\hline PCB $<500 \mu \mathrm{m}$ & $\begin{array}{l}\text { At. thiooxidans and At. } \\
\text { ferrooxidans }\end{array}$ & $\begin{array}{l}>90 \% \mathrm{Cu} \text { extraction in two-stages during } 7 \text { and } \\
10 \text { days at } 5-10 \mathrm{~g} / \mathrm{L} \text { of } \mathrm{PCB} ; 35^{\circ} \mathrm{C} \text { and } 180 \mathrm{~min}^{-1}\end{array}$ & Shaking flask & $\begin{array}{l}\text { Brandl et al. } \\
\text { (2001) }\end{array}$ \\
\hline $\mathrm{PCB}<80$ mesh & $\begin{array}{l}\text { Genera Acidithiobacillus and } \\
\text { Gallionella }\end{array}$ & $\begin{array}{l}95 \% \text { of } \mathrm{Cu} \text { in } 5 \text { days at } 9 \mathrm{~g} / \mathrm{L} \text { of initial } \mathrm{Fe}^{2+}, 20 \mathrm{~g} / \mathrm{L} \text { of } \\
\mathrm{PCB} \text { and } \mathrm{pH} 1.5 \text {; shaker at } 30^{\circ} \mathrm{C} \text { and } 120 \mathrm{~min}^{-1}\end{array}$ & Shaking flask & $\begin{array}{l}\text { Xiang et al. } \\
(2010)\end{array}$ \\
\hline PCB $100-120 \mu \mathrm{m}$ & $\begin{array}{l}\text { S. thermosulfidooxidans and } \\
\text { Thermo- plasma acidophilum }\end{array}$ & $\begin{array}{l}86 \% \mathrm{Cu} \text { extraction. Acid pre-leaching of } 27 \text { days and } \\
\text { bioleaching of } 280 \text { days. Column reactor at } 45^{\circ} \mathrm{C}\end{array}$ & Column reactor & Ilyas et al. (2010) \\
\hline PCB 60-80 mesh & Enriched acidophilic bacteria & $\begin{array}{l}96.8 \% \mathrm{Cu} \text { extraction in } 45 \mathrm{~h} ; 12 \mathrm{~g} / \mathrm{L} \mathrm{Fe}^{2+}, 12 \mathrm{~g} / \mathrm{L} \mathrm{PCB} \\
\text { and } \mathrm{pH} 2 \text {; shaker at } 30^{\circ} \mathrm{C} \text { and } 160 \mathrm{~min}^{-1}\end{array}$ & Shaking flask & Zhu et al. (2011) \\
\hline $\begin{array}{l}\text { TV circuit boards } \\
\qquad(\text { STVB })<250 \mu \mathrm{m}\end{array}$ & $\begin{array}{l}\text { At. ferrooxidans, L. ferrooxidans } \\
\text { and At. thiooxidans }\end{array}$ & $\begin{array}{l}35 \% \mathrm{Cu} \text { extraction in } 90 \mathrm{~h} \text { without external } \mathrm{Fe}^{2+} \text { and } \\
89 \% \mathrm{Cu} \text { extraction at } 8 \mathrm{~g} / \mathrm{L} \mathrm{Fe}^{2+} \text { at } 10 \mathrm{~g} / \mathrm{L} \text { of } \mathrm{PCB} \text { and } \\
\mathrm{pH} 1.7 \text {; shaker at } 35^{\circ} \mathrm{C} \text { and } 170 \mathrm{~min}^{-1}\end{array}$ & Shaking flask & Bas et al. (2013) \\
\hline РCB $50-150 \mu \mathrm{m}$ & $\begin{array}{l}\text { S. thermosulfidooxidans and } T \text {. } \\
\text { acidophilum }\end{array}$ & $\begin{array}{l}85 \% \mathrm{Cu} \text { extraction in } 18 \text { days at } 10 \mathrm{~g} / \mathrm{L} \text { of } \mathrm{PCB} ; \\
\text { shaker at } 45^{\circ} \mathrm{C} \text { and } 180 \mathrm{~min}^{-1}\end{array}$ & Shaking flask & Ilyas et al. (2013) \\
\hline
\end{tabular}

summarized in Table 1. Iron-oxidizing bacteria produces ferric from ferrous iron (Eq. (1)), which can subsequently oxidize metals such as copper according to Eq. (2). In general, mesophilic bacteria belonging to the genus Acidithiobacillus and Leptospirillum are most commonly used in bioleaching.

$$
\begin{aligned}
& \mathrm{Fe}^{2+}+1 / 4 \mathrm{O}_{2}+\mathrm{H}^{+} \rightleftarrows \mathrm{Fe}^{3+}+1 / 2 \mathrm{H}_{2} \mathrm{O} \\
& 2 \mathrm{Fe}^{3+}+\mathrm{Cu}^{0} \rightarrow \mathrm{Cu}^{2+}+2 \mathrm{Fe}^{2+}
\end{aligned}
$$

In addition to these two bacterial genera thermophilic microorganisms may also be employed in bioleaching operations (Brandl et al., 2001; Pant et al., 2012). As a rule, leaching at elevated temperatures has the potential to result in more efficient and faster metal dissolution. In the bioleaching of copper sulfides for instance higher extractions with moderate thermophilies as compared to mesophiles were reported elsewhere (Pina, 2006; Schippers, 2007). Copper bioleaching from e-wastes with moderate thermophilies in shake flasks (Ilyas et al., 2007, 2013; Pina, 2006), stirred tanks (Ilyas et al., 2014) and lab scale columns (Ilyas et al., 2010) were also investigated. However, few studies have studied bioleaching of e-waste and printed circuit boards in particular using moderate thermophiles.

The reactors used in the bioleaching of sulfides are generally designed as stirred tank or air-lift type but concerning e-waste bioleaching there is a limited data about the type of reactor on process performance. A rotating-drum reactor could be suggested as alternative to the stirred-tank reactors with the potential advantage to treat material at increased pulp densities and reduce global energy consumption. It could be assumed that such a reactor will ensure reduced impact on the microbial cells due to the lower degree of collisions between the particles (Liu et al., 2007). Such configuration offers the possibility of using high solid loadings without negatively influencing the bio-oxidation of $\mathrm{Fe}^{2+}$ which tends to be the case when impeller-driven reactors are used (Jin et al., 2013).

The feasibility of copper bioleaching from fine milled PCB at low solids concentrations (up to $10.0 \mathrm{~g} / \mathrm{L}$ ) has been demonstrated and extractions as high as $90 \%$ were reported with mesophililc strains (Bas et al., 2013; Brandl et al., 2001; Xiang et al., 2010; Zhu et al., 2011). Nevertheless, quite few studies dealing with increased solid concentrations have been published so far likely because bacterial growth is inhibited in the presence of fine PCB particles. Although the exact nature of such deleterious effects is still unclear there are indications that are more important in the very beginning of leaching experiments. This is because the quick release of harmful-to-bacteria species from the ground PCB is stimulated.

With the above mentioned concerns in the background, the current work proposes a different approach to PCB bioleaching, in which relatively coarse $\mathrm{PCB}$ sheets are leached without reducing their size down to the micrometer scale. The objective is to avoid useless overgrinding and hence reduce the overall cost associated with the fragmentation step. Another aim is to discuss the bacterial adaptation to increased PCB content and to find out the optimal pH and ferrous iron concentration for bioleaching using moderate thermophiles in a rotating-drum reactor.

\section{Experimental procedure}

\section{1. $P C B$ fragmentation and pre-treatment}

The experiments were carried out with PCB collected from obsolete desktop computers, from which all electronic components such as capacitors and resistors were manually removed in advance. At the beginning, the dismantled boards were shredded using a metal guillotine to obtain nearly rectangular PCB fragments with $20 \mathrm{~mm}$-long size. For the experiments with ground PCB, a fraction from the above-mentioned sheets was further fragmented using a laboratory hammer mill and after dry sieving the $-208 \mu \mathrm{m}+147 \mu \mathrm{m}$ particle size was selected. A second sample was subjected to a "pre-weakening" process in a laboratory jaw crusher (discharge gap $10 \mathrm{~mm}$ ) aiming to generate cracks and to expose metals inside the PCB sheets to the leaching solutions. After jaw crusher "pre-weakening", the samples were screened at $20 \mathrm{~mm}$ and the oversize fraction used for further studies. One part of this oversize material (fraction $+20 \mathrm{~mm}$ ) was subsequently submitted to a chemical pre-treatment step to remove the lacquer coating, which covered the printed circuit boards. PCB sheets $(50 \mathrm{~g})$ were mixed with $500 \mathrm{~mL}$ of aqueous solution of diethylene glycol $(20 \% \mathrm{v} / \mathrm{v})$ and potassium hydroxide $(20 \% \mathrm{w} / \mathrm{v})$ for accomplishing this task. The lacquer coating removal step was carried out under stirring at $90{ }^{\circ} \mathrm{C}$ during in $60 \mathrm{~min}$. Thereafter the solid phase was filtered, washed with distilled water and then dried at $50{ }^{\circ} \mathrm{C}$ to a constant weight.

\subsection{Microorganisms}

The mesophile microorganisms utilized in the current study were isolated from a Brazilian sulfide mine, for which microbial 
diversity studies revealed the predominance of Acidithiobacillus ferrooxidans (Azevedo, 2008). This strain was sub-cultured in a Norris medium $\left(0.2 \mathrm{~g} / \mathrm{L}\left(\mathrm{NH}_{4}\right) \mathrm{SO}_{4}, 0.4 \mathrm{~g} / \mathrm{L} \quad \mathrm{MgSO}_{4} .7 \mathrm{H}_{2} \mathrm{O}\right.$, and $0.1 \mathrm{~g} / \mathrm{L}$ $\left.\mathrm{K}_{2} \mathrm{HPO}_{4}\right)$ with $2.5 \mathrm{~g} / \mathrm{L} \mathrm{Fe}{ }^{2+}\left(\mathrm{FeSO}_{4} \cdot 7 \mathrm{H}_{2} \mathrm{O}\right)$. The procedure was accomplished in an orbital shaker (New Brunswick, Innova 44) at $35^{\circ} \mathrm{C}$ and $150 \mathrm{~min}^{-1}$. Experiments were also carried out with the thermophilic bacterium Sulfobacillus thermosulfidooxidans, purchased from DSMZ - Braunschweig (ID 9293). This strain was maintained in the same Norris growth medium, which was supplemented with yeast extract $(0.1 \mathrm{~g} / \mathrm{L})$. A second orbital shaker (New Brunswick, Innova 44) working at $50^{\circ} \mathrm{C}$ provided mixing $\left(150 \mathrm{~min}^{-1}\right)$. In both cases $\mathrm{pH}$ solution was set at $1.75 \pm 0.05$.

Prior to the bioleaching experiments, the two bacterial strains were inoculated to both crushed $(-208 \mu \mathrm{m}+147 \mu \mathrm{m})$ and to non-crushed $(20 \mathrm{~mm})$ PCB. Adaptation was performed by selecting a bacterial inoculum during its $\log$ phase (as indicated by redox potential values around $550 \mathrm{mV}$ ) and its transfer to the growth medium, while progressively increasing the PCB content (starting at $5.0 \mathrm{~g} / \mathrm{L}$ solids $(\mathrm{w} / \mathrm{v})$ up to $10.0 \mathrm{~g} / \mathrm{L}$ for the crushed PCB and to $25.0 \mathrm{~g} / \mathrm{L}$ in the case of non-crushed PCB). Culture replications were performed on a weekly basis to maintain a bacterial population well adapted to PCB.

\subsection{Bioleaching experiments}

Bioleaching of ground PCB was carried out in 250-mL Erlenmeyer flasks placed in a thermostated shaker (New Brunswick Innova 44) at the Bio and hydrometallurgy laboratory of the Federal University of Ouro Preto (Brazil). Both mesophile and moderate thermophile cultures were tested under the procedure described in Section 2.2, unless otherwise stated. A suspension containing $10.0 \mathrm{~g} / \mathrm{L}$ of ground PCB $(-208 \mu \mathrm{m}+147 \mu \mathrm{m})$ was prepared using $100 \mathrm{~mL}$ of growth medium, $10 \%$ of inoculum and ferrous sulfate in predetermined concentration. Initial ferrous iron concentration was varied between $1.25 \mathrm{~g} / \mathrm{L}$ and $10.0 \mathrm{~g} / \mathrm{L}$ and the $\mathrm{pH}$ was maintained at $1.75 \pm 0.05$ using $1 \mathrm{~mol} / \mathrm{L}$ sulfuric acid or $6 \mathrm{~mol} /$ $\mathrm{L}$ sodium hydroxide. Evaporation losses during leaching were corrected by adding distilled water to the initial recorded weight. Pulp redox potential was registered using a WTW 315 multi-meter (vs. an $\mathrm{Ag} / \mathrm{AgCl}$ electrode). Sterile controls were also run in the presence of bactericide: thymol (for the mesophiles) or a mixture of $0.015 \%(\mathrm{v} / \mathrm{v})$ methylparaben and $0.01 \%(\mathrm{v} / \mathrm{v})$ propylparaben solution for the tests with moderate thermophile performed in the presence and absence of ferrous iron.

Another series of bioleaching experiments were performed batchwise with the $20 \mathrm{~mm}$-long PCB fragments at a solid loading of $25.0 \mathrm{~g} / \mathrm{L}$ in shake flasks, following the above cited procedure, but only with $S$. thermosulfidooxidans at $50{ }^{\circ} \mathrm{C}$. After defining the optimal $\mathrm{pH}$ and ferrous iron initial concentration larger scale experiments were carried out at the Mineral Processing and Recycling Unit, University of Liege (Belgium) using a rotating-drum reactor pictured in Fig. 1. The reactor consisted of a perforated drum (with $10 \mathrm{~mm}$ openings) driven by a motor and fitted with a gas sparger (not shown in the sketch) to provide aeration with air. The perforated drum was immersed inside a fixed cylindrical compartment containing the liquid medium/pregnant leach solution. An air (fan) heater was placed as close as possible to the drum reactor in order to maintain the temperature inside the reactor at $50 \pm 1{ }^{\circ} \mathrm{C}$.

The experiments were performed at rotation speed of $80 \mathrm{~min}^{-1}$ using $300 \mathrm{~g}$ of $20 \mathrm{~mm}$-long PCB sheets immersed in $12 \mathrm{~L}$ of medium containing $10 \%(\mathrm{v} / \mathrm{v})$ of inoculum so that a $25.0 \mathrm{~g} / \mathrm{L}$ pulp density was achieved. The effect from the initial $\mathrm{Fe}^{2+}$ concentration ( $2.5 \mathrm{~g} / \mathrm{L}, 5.0 \mathrm{~g} / \mathrm{L}, 7.5 \mathrm{~g} / \mathrm{L}$ and $10.0 \mathrm{~g} / \mathrm{L}$ ) on copper extraction was also assessed during these experiments. At predetermined intervals, $5 \mathrm{~mL}$ aliquot was sampled from the leach solution and delivered

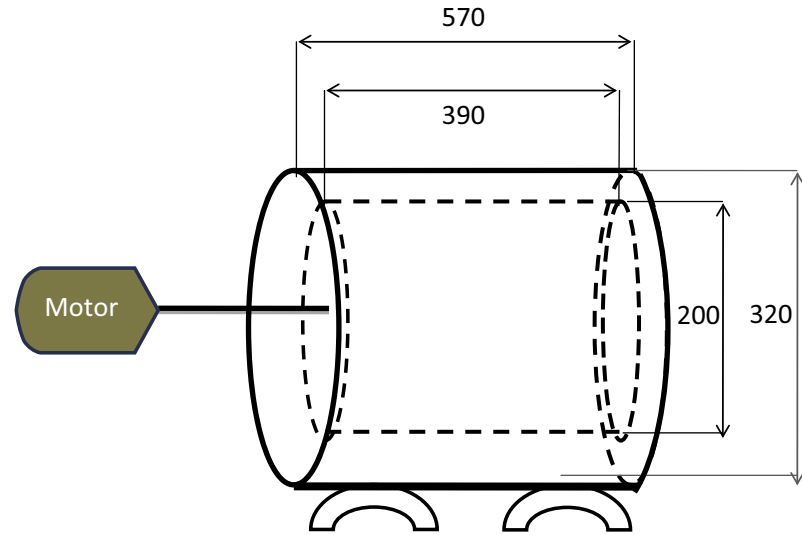

Fig. 1. Schema of the rotating-drum reactor (all dimensions in $\mathrm{mm}$ ).

to elemental analysis. Redox potential and $\mathrm{pH}$ were recorded and maintained, similarly to the shaking flask tests.

\subsection{Analysis and characterization}

Metal concentration in the solid PCB was determined by inductively coupled plasma -atomic emission spectrometry (ICP-AES) Varian Series II, following sample $(1.0 \mathrm{~g})$ digestion with aqua regia and dilution in $250 \mathrm{~mL}$ volumetric flasks. All chemical analysis for the solid phases were carried out in triplicate and the mean value used. The global assay of the PCB has indicated that the base metals accounted for approximately $30 \%$ of the sample, with copper being present in majority $(28.5 \pm 0.1 \%)$. Fe $(0.51 \%), \mathrm{Zn}(0.41 \%)$ and $\mathrm{Ni}$ $(0.07 \%)$ have also been detected. Metal concentrations in the leach solutions were likewise determined by ICP-AES and used for calculation of copper extraction.

Ferrous iron was assayed by titration with standard potassium dichromate solution in the presence of a $1 \mathrm{M} \mathrm{H}_{2} \mathrm{SO}_{4}: 1 \mathrm{M} \mathrm{H}_{3} \mathrm{PO}_{4}$ using barium diphenylamine sulfonate as indicator. The concentration of $\mathrm{Fe}^{3+}$ was calculated from the difference between total iron and $\mathrm{Fe}^{2+}$ concentrations. The acid consumption was determined considering the amount of sulfuric acid (98\%) used for keeping $\mathrm{pH}$ constant during leaching in rotating-drum reactor. The surface morphology and the internal structure of the PCB were studied by SEM (Tescan Vega 3). Energy dispersive X-ray spectroscopy (EDS) (Oxford) was used to quantify the residues after leaching and to detect residual copper inside leached PCB as well. All chemicals used in this study were of analytical grade (AR) unless otherwise stated and all solutions were prepared with distilled water.

\section{Results and discussion}

\subsection{Bioleaching in shake flasks}

\subsubsection{Effect of pulp density and initial ferrous iron concentration}

The heterogeneous composition of PCB sheets, which contain metals, polymers and ceramics (Ilyas et al., 2010; Zhu et al., 2013) could induce inhibiting effects on bacterial growth during bioleaching, although the exact compounds accounting for such effects remain unclear (Brandl et al., 2001). In the current work, such inhibiting effects were verified through solution potential (Eh), which is an indirect assessment of bacterial growth in the reactor. Fig. 2(a) and (b) shows similar Eh profiles both in the presence and absence of PCB only for solid contents of up to $2.5 \mathrm{~g} / \mathrm{L}$ at both temperatures when ground PCB $(-208 \mu \mathrm{m}+147 \mu \mathrm{m})$ was bioleached in the presence of $2.5 \mathrm{~g} / \mathrm{L} \mathrm{Fe}^{2+}$, prior to bacterial adaptation. Impaired bacterial growth was inferred at higher PCB content $(5.0 \mathrm{~g} / \mathrm{L}$ and $10.0 \mathrm{~g} / \mathrm{L})$ because the solution potential remained 

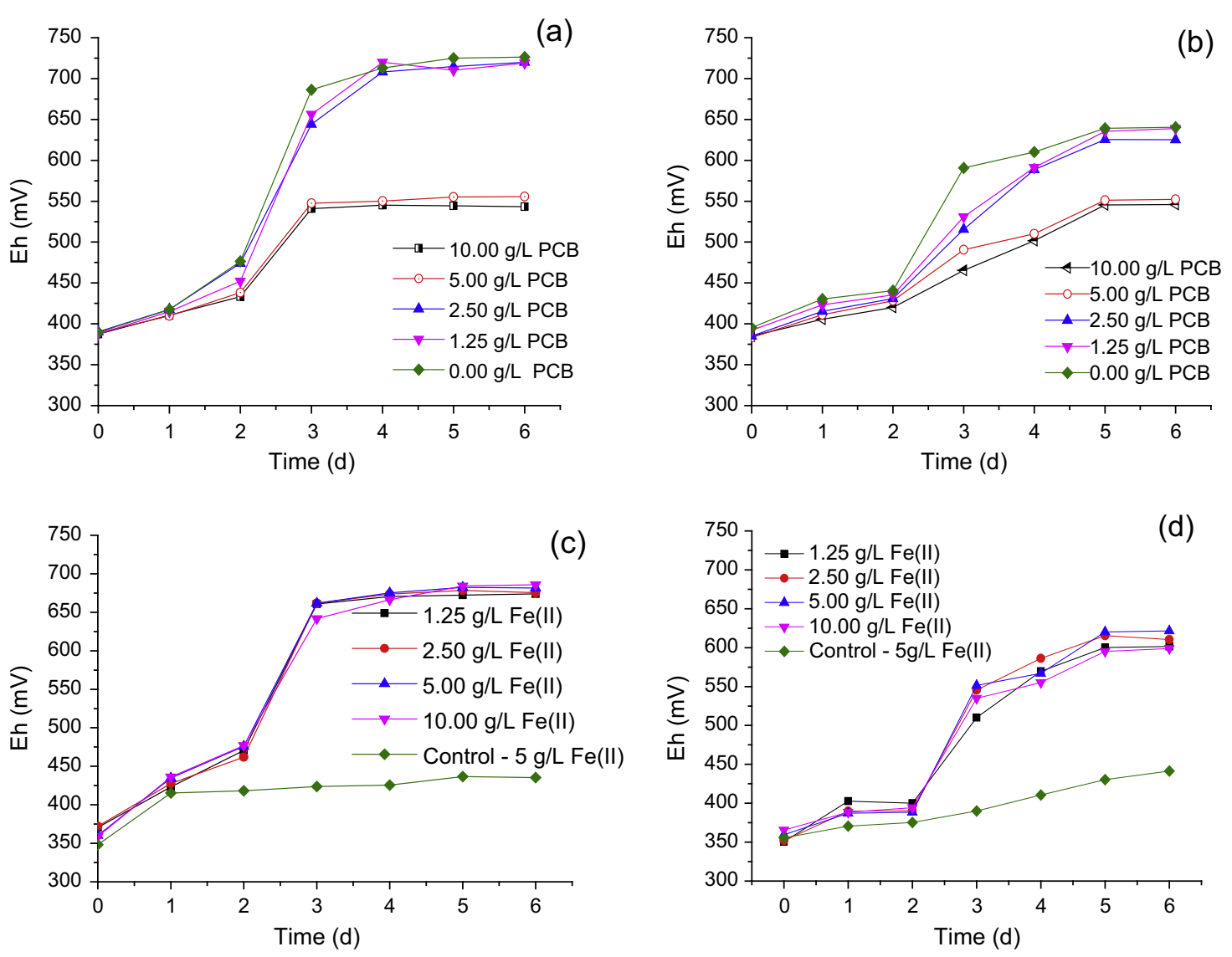

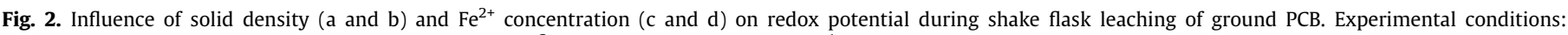
temperature $30^{\circ} \mathrm{C}\left(\mathrm{a}\right.$ and $\mathrm{c}$ ) and $50{ }^{\circ} \mathrm{C}(\mathrm{b}$ and $\mathrm{d}), 2.5 \mathrm{~g} / \mathrm{L} \mathrm{Fe}^{2+}\left(\mathrm{a}\right.$ and b), $\mathrm{pH} 1.75 ; 150 \mathrm{~min}^{-1}$; pulp density of $10.0 \mathrm{~g} / \mathrm{L}(\mathrm{c}$ and d).

below that observed with lower solid content $(2.5 \mathrm{~g} / \mathrm{L})$, leveling out at $550 \mathrm{mV}$ between day $3\left(\right.$ at $30^{\circ} \mathrm{C}$ ) and 5 (at $50^{\circ} \mathrm{C}$ ). If detrimental effects were absent, Eh values between 650 and $700 \mathrm{mV}$ would be expected, irrespective of the strain studied as observed in the experiment with no $\mathrm{PCB}$.

After adaptation to ground PCB, an Eh increase was observed in the presence of $10.0 \mathrm{~g} / \mathrm{L}$ solids at both temperatures and values around $650 \mathrm{mV}$ were recorded at $30^{\circ} \mathrm{C}$ within three days (Fig. 2(c)) irrespective of the initial $\mathrm{Fe}^{2+}$ concentration. Similar behavior was depicted in the experiments with $S$. thermosulfidooxidans, at $50^{\circ} \mathrm{C}$, but with slightly lower Eh values (around $600 \mathrm{mV}$ ) as depicted in Fig. 2(d). This difference was most likely because both microorganisms have different ferrous iron oxidation rates. Furthermore, the control experiments performed at the concentration of $5.0 \mathrm{~g} / \mathrm{L}$ of $\mathrm{Fe}^{2+}$ showed Eh values around $450 \mathrm{mV}$, clearly indicating a lack of $\mathrm{Fe}^{2+}$ oxidation in the absence of each bacteria. Fig. 3(a) and (b) present copper extractions at different ferrous iron concentration for mesophiles and moderate thermophiles, respectively. Copper was almost completely extracted in 5 and 3 days, at $30^{\circ} \mathrm{C}$ and $50^{\circ} \mathrm{C}$, respectively, when bioleaching was performed with adapted bacteria. These periods are similar to that reported by Xiang et al. (2010), who studied PCB leaching ( $20 \mathrm{~g} / \mathrm{L}$ ) with At. ferrooxidans. Conversely, Ilyas et al. (2013) reported a lag phase of 5 days during bioleaching with $S$. thermosulfidooxidans in the presence of $7 \mathrm{~g} / \mathrm{L}$ PCB. The same authors carried out experiments with increasing PCB content and observed that at $22 \mathrm{~g} / \mathrm{L} \mathrm{PCB}$ there was no efficient leaching of metallic copper, indicating that such solid content did not enable bacterial growth.

It is acknowledged that dissolution of metallic copper requires an oxidizing agent as suggested by Eq. (2). Therefore higher initial $\mathrm{Fe}^{2+}$ concentrations would result in faster dissolution rates of metallic copper (assuming that bioleaching proceeds via the indirect non-contact mechanisms), which was confirmed in Fig. 3(a) and (b). Actually, increasing $\mathrm{Fe}^{2+}$ concentrations up to $10.0 \mathrm{~g} / \mathrm{L}$ exercised a positive effect on copper leaching in both systems (mesophiles and moderate thermophiles) because copper extractions of $94 \%$ and $99 \%$ were achieved using mesophilic and moderate thermophile cultures, respectively. Nevertheless, a concentration of $5.0 \mathrm{~g} / \mathrm{L}$ ferrous iron could be considered as an optimal value in both cases. Furthermore $48 \%$ and $53 \%$ copper extractions were observed in the abiotic controls containing $5 \mathrm{~g} / \mathrm{L} \mathrm{Fe}^{2+}$ at $30{ }^{\circ} \mathrm{C}$ and $50{ }^{\circ} \mathrm{C}$, respectively (Fig. 3(a) and (b)), highlighting the positive effect of the presence of bacteria. It is worth noting that bioleaching studies carried out with ground PCB $(50-150 \mu \mathrm{m})$ performed by Ilyas et al. (2007) using moderate thermophilic microorganisms and $10.0 \mathrm{~g} / \mathrm{L}$ of PCB showed slightly lower copper extractions than those achieved in the current study $(>94 \%)$, in the $72-89 \%$ range over a period of 18 days.

Ferrous iron bio-oxidation plays a key role in copper dissolution as suggested by the low copper extraction in the control experiments (control tests) performed in the presence and absence of ferrous ions (Fig. 3(a) and (b)). In the tests without ferrous iron addition, copper extractions reached $21.7 \%$ and $28 \%$ at $30{ }^{\circ} \mathrm{C}$ and $50{ }^{\circ} \mathrm{C}$, respectively, i.e., Figures lower than those achieved in the control test. The fact that the experiments with $5.0 \mathrm{~g} / \mathrm{L}$ always outperform those with no external ferrous iron indicates that the chemical oxidation of ferrous iron by oxygen was much faster than the oxidation of metallic copper by the same oxidant (Eq. (3)). Copper leaching in the latter case was governed by the oxygen introduced in the system by stirring (Bas et al., 2013; Brandl et al., 2001).

$\mathrm{Cu}^{0}+1 / 2 \mathrm{O}_{2}+2 \mathrm{H}^{+} \rightarrow \mathrm{Cu}^{2+}+\mathrm{H}_{2} \mathrm{O}$ 

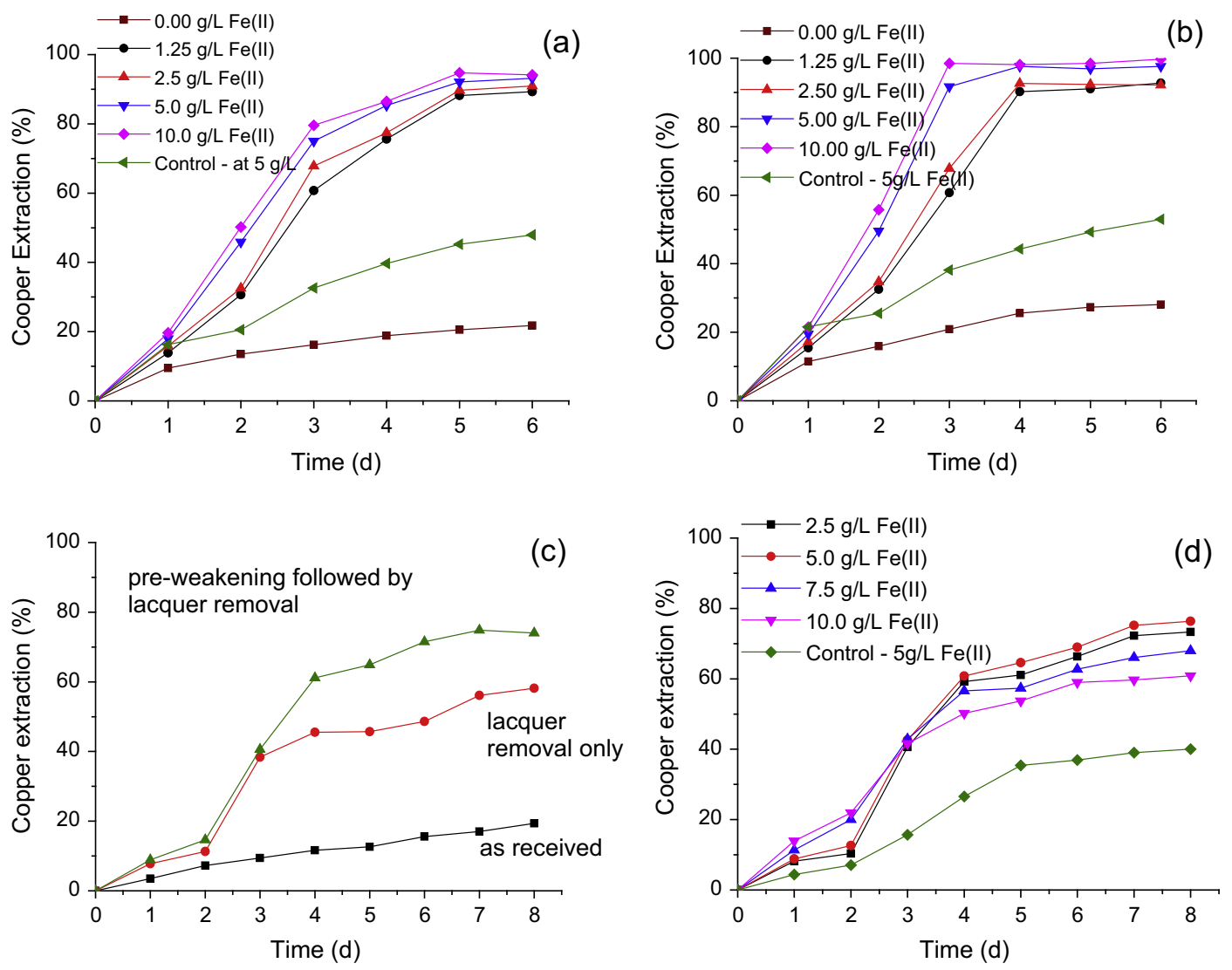

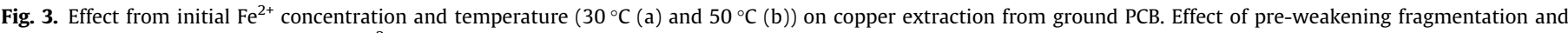

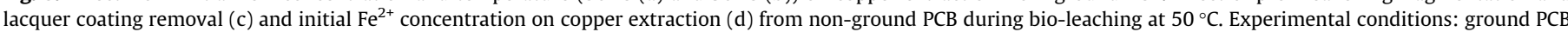

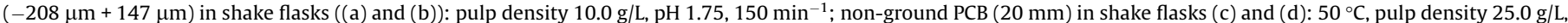
$5.0 \mathrm{~g} / \mathrm{L} \mathrm{Fe}^{2+}, \mathrm{pH} 1,75,150 \mathrm{~min}^{-1}$.

Although bioleaching could be performed in the presence of $10.0 \mathrm{~g} / \mathrm{L}$ ground PCB, adaptation of both strains to higher PCB content was not possible during the course of the current study. Therefore, the investigation shifted to the bioleaching of nongrounded PCB (20 mm-long sheets), expecting that the release of harmful-to-microorganisms compounds could be limited. Under such conditions, bacterial adaptation could be facilitated however copper extraction might be reduced due to the non-complete liberation of metallic copper. Another advantage of this approach would be the possible cost reduction due to the elimination of fine grinding. Therefore, the subsequent series of experiments were envisaged using explicitly coarser non-ground PCB and $S$. thermosulfidooxidans was selected due to the faster leaching kinetics fostered by higher temperatures.

\subsubsection{Experiments with $20 \mathrm{~mm}$-long $P C B$ sheets}

With PCB sheets $S$. thermosulfidooxidans could tolerate pulp densities of up to $25 \mathrm{~g} / \mathrm{L}$. In addition, two pretreatments were performed to expose copper inside the $20 \mathrm{~mm}$-long sheets: (i) preweakening" i.e. fragmentation in a jaw crusher and (ii) removal of the lacquer coating the sheets.

Fig. 3(c) report on the results of the tests with such PCB fragments at $25.0 \mathrm{~g} / \mathrm{L}$ solids, in which the effect of PCB "pre-weakening" and lacquer removal on copper extraction were assessed. As shown in Fig. 3(c) the effect of lacquer removal was evident, with nearly $60 \%$ copper recovery as compared to merely $20 \%$ extraction from the "as received" PCB. Combining pre-weakening and lacquer removal brought further positive effects on copper extraction which attained $70 \%$, against $60 \%$ with lacquer removal only (Fig. 3(c)).
To explain the phenomena observed during PCB bioleaching, microscopic observations of PCB samples before and during bioleaching were carried out. Fig. 4(a) shows a SEM image of a cross-sectional area of an "as-received" $20 \mathrm{~mm}$-long PCB fragment. It could be concluded that copper is present as four layers (two internal and two external) sandwiched between fiberglass and polymer structures, possibly an epoxy resin (Zhu et al., 2013). Furthermore, Fig. 4(b) and (c) depict details of a cross-sectional area of a PCB sheet before and after lacquer removal, whereas Fig. 4(d) and (e) shows a frontal view of PCB surface with and without lacquer coating, respectively. The purpose of the lacquer coating seen in Fig. 4(b) and (d) was to prevent the copper surface from oxidation. However, it also hindered copper bioleaching by restricting the access of the oxidizing agent $\left(\mathrm{Fe}^{3+}\right)$ toward the metal surface. Removal of the lacquer coating as seen in Fig. 4(c) and (e) exposed the copper layers, facilitating metal leaching.

The dissolution of copper before and after PCB "pre-weakening" by means of a jaw crusher can be seen in the SEM images 5(a) and 5 (b), respectively. Cracks introduced in the PCB resulted in an improvement in copper extraction by facilitating solution diffusion toward the inner PCB layers (Fig. 5(b)). In particular the jaw crusher impact has provoked cracks to emerge inside PCB structure as could be seen from the SEM images in Fig. 5(b). Thus the "preweakened" polymer and fiberglass structure has favored the leaching solutions to access the copper surface.

For the PCB sample submitted to both jaw crushing and lacquer removal, further tests assessed the effect of the initial ferrous iron concentration on copper leaching as shown in Fig. 3(d). The results indicate copper extraction of nearly $76 \%$ in the presence of $5.0 \mathrm{~g} / \mathrm{L}$ ferrous iron (the best result) within eight days of leaching with $S$. 

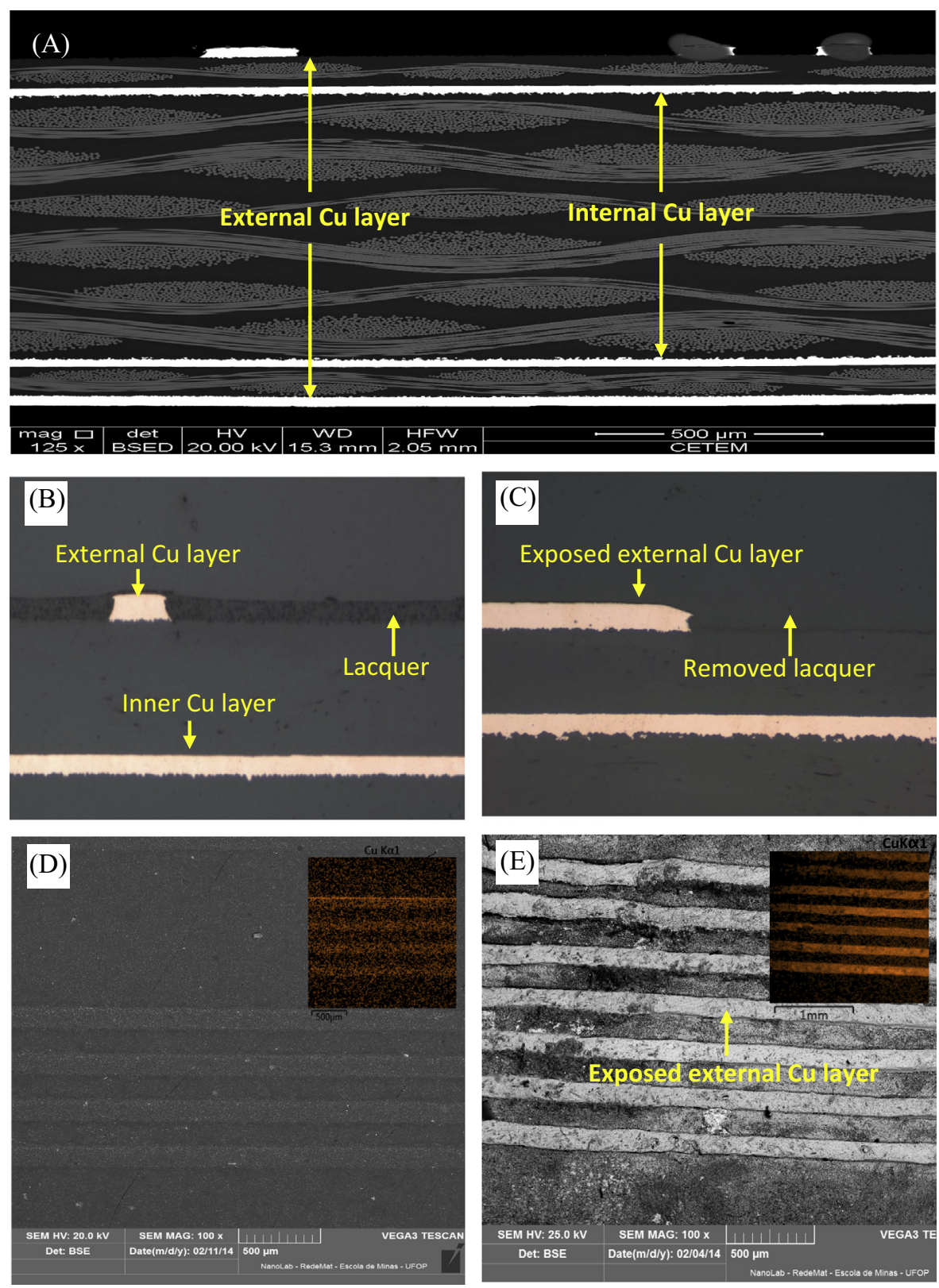

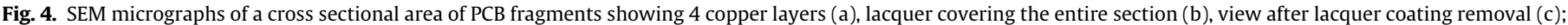
SEM frontal view of PCB surface with lacquer coating (d) and after removal of the lacquer coating (e).

thermosulfidooxidans. However, such outcome is lower than the one observed with the ground PCB (97\%) and might be ascribed to the smaller degree of copper exposure at coarser particle sizes. Jarosite precipitation on the PCB surface was detected in the tests with $7.5 \mathrm{~g} / \mathrm{L}$ and $10.0 \mathrm{~g} / \mathrm{L} \mathrm{Fe}^{2+}$ as inferred from Fig. 6, in which a precipitate (most likely jarosite) was observed after eight days of leaching. Other elements were also observed, which come from the elements forming the PCB sheet (Dang et al., 2008; Ilyas et al., 2013). In these two initial $\mathrm{Fe}^{2+}$ concentrations the copper extraction was reduced (Fig. 3(d)).

\subsubsection{Effect of pulp $\mathrm{pH}$ the on degree of copper extraction}

It is known that bacterial growth and substrate utilization are influenced by $\mathrm{pH}$ solution (Bhatti et al., 2012; Dopson et al., 2008, 2009). More precisely values below pH 1.2 have been shown to hamper $S$. thermosulfidooxidans growth whereas jarosite precipitation depletes solution from ferric iron when $\mathrm{pH}$ is increased to values above 2. Moreover according to Petersen and Dixon (2007a) microbial activity is also affected when the pH is maintained above this value. The effects of $\mathrm{pH}$ on both leaching kinetics and copper extraction is witnessed by tests at the optimal ferrous iron concentration of $5.0 \mathrm{~g} / \mathrm{L}$. Fig. 7 shows the effect of $\mathrm{pH}$ on copper dissolution during bioleaching with $S$. thermosulfidooxidans already adapted to PCB. The perusal of the results indicates that copper extraction reached $76 \%$ within one week when $\mathrm{pH}$ was maintained at 1.5 and 1.75 . The $\mathrm{pH}$ value of 1.75 was selected for the subsequent series of experiments in the rotating-drum reactor because it would have favorable effects on acid consumption, an issue with direct practical implications.

\subsection{Bioleaching in the rotating-drum reactor}

The effect of ferrous iron concentration on copper bioleaching inside the rotating-drum reactor was investigated in the presence of $S$. thermosulfidooxidans at $50{ }^{\circ} \mathrm{C}, \mathrm{pH} 1.75$. From the results reported thus far (Fig. 3(c)) it was conceivable that moderate 

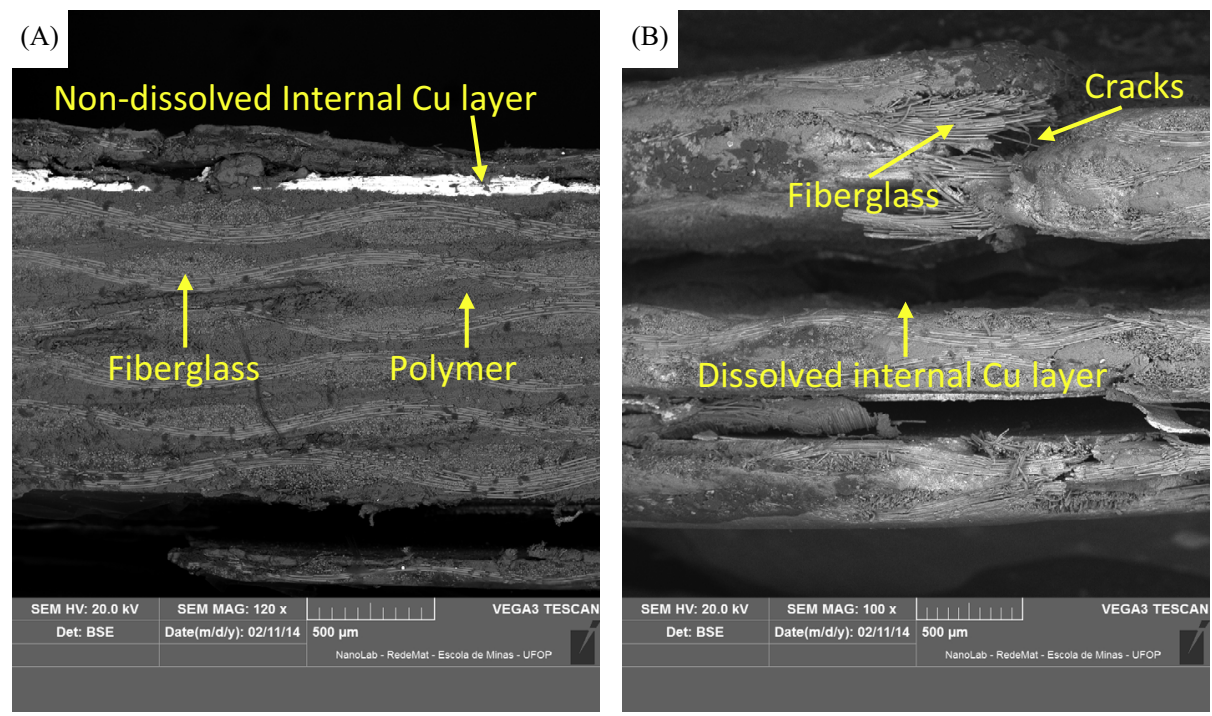

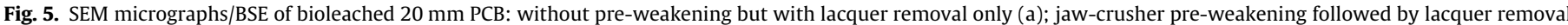
(b). Experimental conditions in rotating drum reactor: $50{ }^{\circ} \mathrm{C}$, pulp density $25.0 \mathrm{~g} / \mathrm{L}, \mathrm{pH} 1.75,80 \mathrm{~min}^{-1}$.

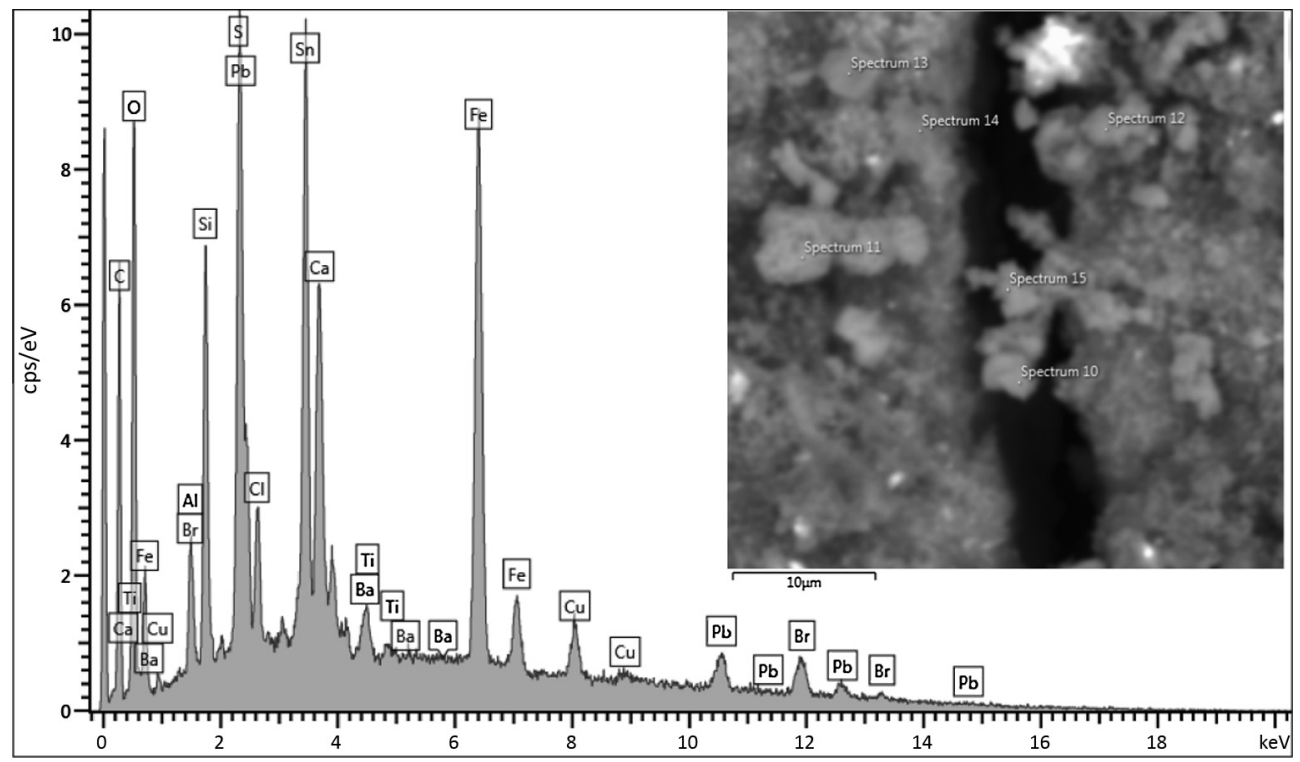

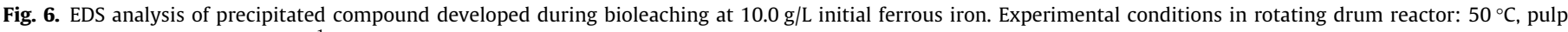
density $25.0 \mathrm{~g} / \mathrm{L}, \mathrm{pH} 1.75,80 \mathrm{~min}^{-1}$.

thermophiles would be able to withstand elevated solid loadings of the coarse PCB sheets in the drum reactor. Therefore the experimental program in this reactor was performed at $25.0 \mathrm{~g} / \mathrm{L}$ solids using jaw-crushed and lacquer-free PCB.

Fig. 8(a) shows the evolution of Eh in the rotating-drum reactor. Under all conditions tested the Eh trend suggested good bacterial growth. In the test aiming at ferrous iron oxidation in the absence of PCB, Eh values above $550 \mathrm{mV}$ were observed after the fourth day; an observation confirming the relatively fast bacterial growth in the reactor. When PCB was present, a slower increase in Eh was observed regardless of the amount of ferrous iron initially present. Nevertheless, the highest Eh values were achieved for $2.5 \mathrm{~g} / \mathrm{L}$ and $5.0 \mathrm{~g} / \mathrm{L}$ ferrous iron concentrations. Moreover, Fig. 9(a) suggests that when $\mathrm{Fe}^{2+}$ was supplied at initial concentration of $7.5 \mathrm{~g} / \mathrm{L}$ and $10.0 \mathrm{~g} / \mathrm{L}$ (implying in theoretically higher $\mathrm{Fe}^{3+}$ concentrations), lower final copper extractions were observed in comparison to the tests at $5.0 \mathrm{~g} / \mathrm{L}$. It could be inferred that increasing the initial ferrous iron concentration to $7.5 \mathrm{~g} / \mathrm{L}$ and $10.0 \mathrm{~g} / \mathrm{L}$ coupled with the elevated temperature might have contributed to iron precipitation and hence to lowering redox potential. This hypothesis is supported by the results seen in Fig. 8(b) which presents the highest reduction in the $\mathrm{Fe}_{\text {tot }}$ concentration in the leaching system with time for experiments with $7.5 \mathrm{~g} / \mathrm{L}$ and $10.0 \mathrm{~g} / \mathrm{L}$. Fig. 8(b) also suggests that the jarosite formation might have hampered copper dissolution by blocking the lixiviant access to the metallic copper.

As mentioned above, the highest degree of copper extraction corresponding to $85 \%$ was reached after seven days for the test performed with $5.0 \mathrm{~g} / \mathrm{L}$ of $\mathrm{Fe}^{2+}$ - Fig. 9(a). This level of extraction when compared to $44 \%$ for the control experiment supports the indirect mechanism hypothesis in which the bacteria oxidizes $\mathrm{Fe}^{2+}$ to $\mathrm{Fe}^{3+}$ in solution and the latter diffuses to the metal-solution interface to dissolve metallic copper from PCB (Crundwell, 2003; Watling 


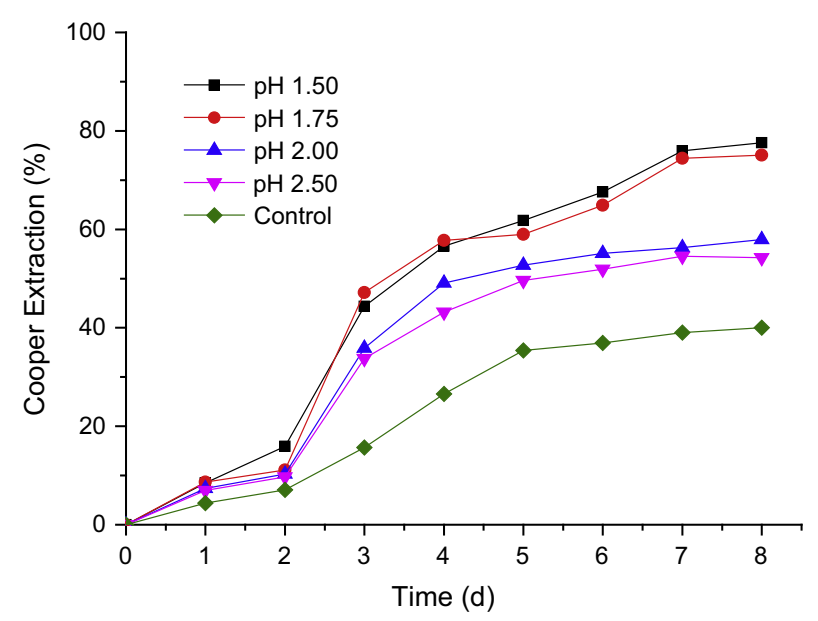

Fig. 7. Influence of $\mathrm{pH}$ on the extraction of copper during bioleaching of nonground PCB in shake flasks. Experimental conditions: $50{ }^{\circ} \mathrm{C}$, pulp density $25.0 \mathrm{~g} / \mathrm{L}$, $5.0 \mathrm{~g} / \mathrm{L} \mathrm{Fe}^{2+}, 150 \mathrm{~min}^{-1}$.
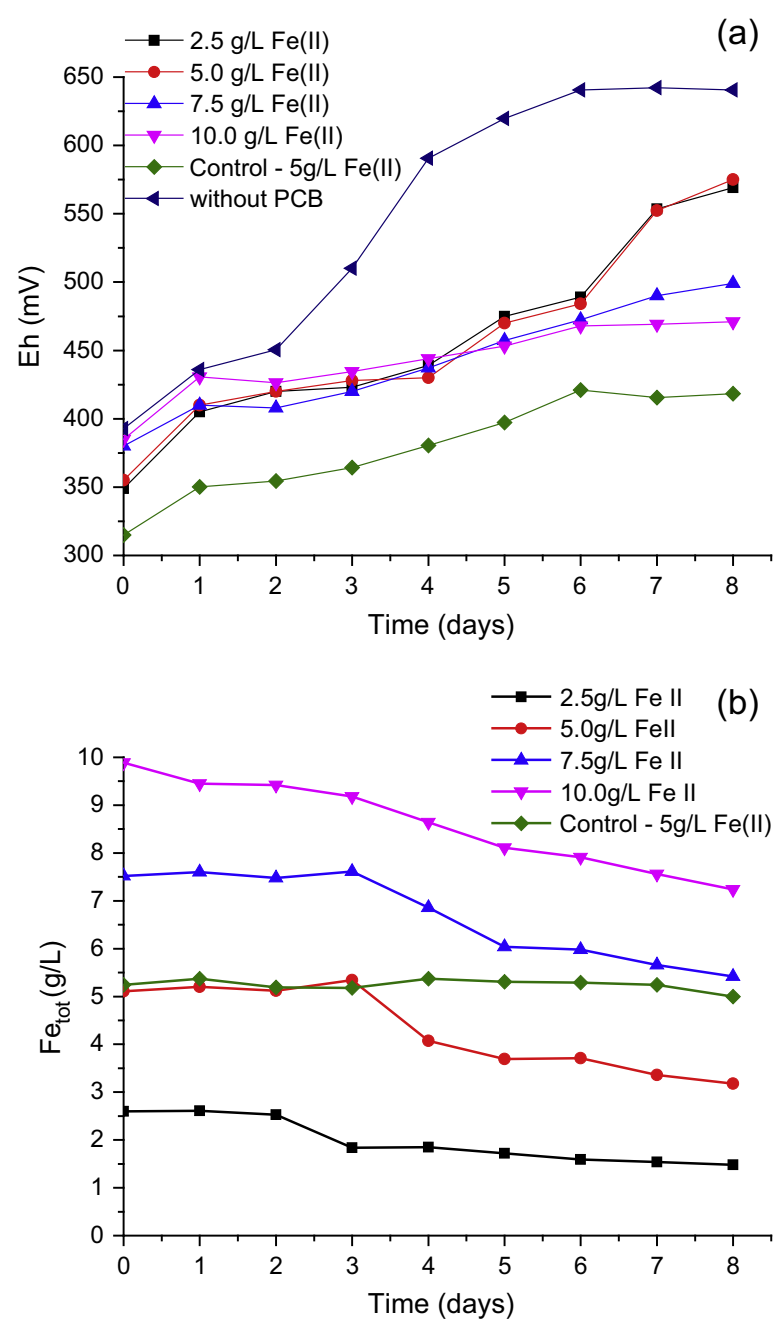

Fig. 8. Influence of initial ferrous iron concentration on redox potential (a) and on $\mathrm{Fe}_{\text {tot }}$ concentration (b) in rotating drum reactor. Experimental conditions: $50{ }^{\circ} \mathrm{C}$, pulp density $25.0 \mathrm{~g} / \mathrm{L}, \mathrm{pH} 1.75,80 \mathrm{~min}^{-1}$.

et al., 2008). It should also be added that jarosite precipitation (Fig. 6) could act as either a diffusion barrier for the oxidant toward the metal surfaces (Zhu et al., 2011) or reduce the total available

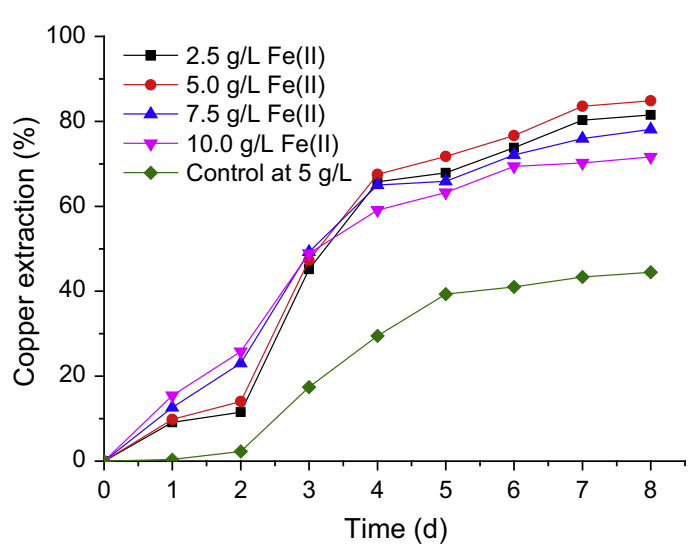

(a)

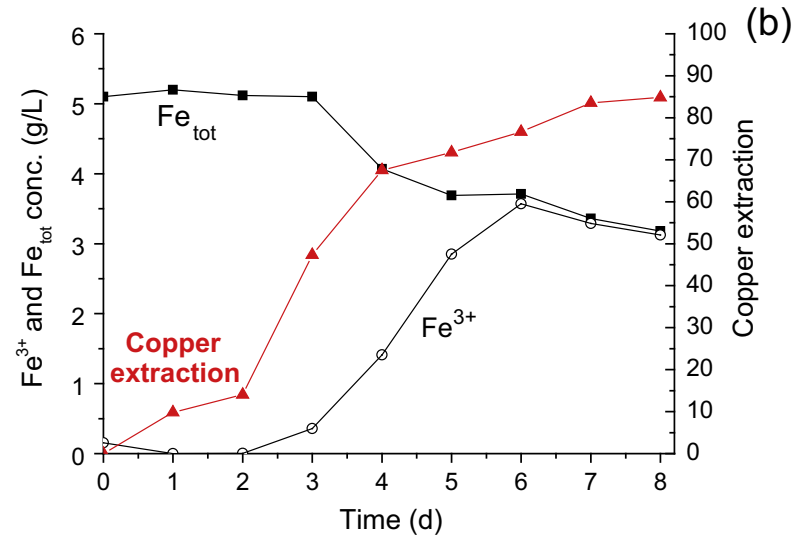

Fig. 9. Effect of initial ferrous iron concentration on copper extraction (a) and evolution of concentration of total and ferric iron and copper extraction degree with $5.0 \mathrm{~g} / \mathrm{L} \mathrm{Fe}^{2+}$ (b) in rotating drum reactor. Experimental conditions: $50{ }^{\circ} \mathrm{C}$, pulp density $25.0 \mathrm{~g} / \mathrm{L}, \mathrm{pH} 1.75,80 \mathrm{~min}^{-1}$.

oxidant concentration. It is known that jarosite precipitation is spontaneous at $\mathrm{pH}$ values above 2.2 , but the precipitation kinetics is chemically controlled, which means that when temperature increases, precipitation takes place even at $\mathrm{pH}$ below 2.0 which is the case in the current work (Daoud and Karamanev, 2006; Ozkaya et al., 2007; van Hille et al., 2010). In addition although every measure has been taken to maintain $\mathrm{pH}$ at constant value of 1.75 , the fact that $\mathrm{pH}$ control was done manually could not exclude that at certain leaching periods slight $\mathrm{pH}$ increase occurred.

Experiments with $5.0 \mathrm{~g} / \mathrm{L}$ ferrous iron lead to a marked increase in copper leaching kinetics after $48 \mathrm{~h}$, reaching $75 \%$ extraction in the following three days (day 2-5), accompanied by a concomitant raise in ferric iron concentration inside the rotating-drum reactor Fig. 9(b). In such a way the results pictured in Fig. 9(b) are confirming the hypothesis of fast bacterial growth already suggested by the Eh trend seen in Fig. 8(a). Nevertheless, it should be mentioned that the relatively low Eh values shown in Fig. $8(\mathrm{a})(<550 \mathrm{mV})$ could be explained by the fast consumption of ferric iron due to its reaction with metallic copper (Eq. (2)). Consequently, Eh values were low and similar to those recorded at non-inoculated systems (Petersen and Dixon, 2007b). Moreover Fig. 9(a) and (b) suggest that copper leaching was low at the beginning of the experiment (until day 2). During this period the process was limited by the $\mathrm{Fe}^{3+}$ concentration (lag phase) and when ferric iron started to emerge it was directly consumed by the metallic copper. Between days 2 and 4 ferric iron accumulated in solution and as a consequence the copper dissolution kinetics was accelerated. Metal dissolved during this period came mostly from the external copper layers in the PCB sheets as implied from Fig. 10. 
Furthermore, such increase in ferric iron concentration (Fig. 9(b)) could be explained by the reduction of copper available from the external layers as suggested by Fig. 10 (please compare the $y$ scale in both figures). The EDS analysis revealed that metal dissolution did not occur uniformly on the entire external copper surface, as expected for an electrochemical mechanism (Fig. 10). Fig. 10 also suggested that the outer copper layer began to disappear and metal dissolution slowed down after four days as also inferred from Fig. 9(a). The presence of polymer and fiberglass shown in Fig. 5(a) and (b)) might have contributed to slow lixiviant diffusion toward the internal metallic copper and restricted the total recovery to $85 \%$ after seven days - Fig. 9(b).

As expected, the redox potential was lower in the control experiment - Fig. 8(a) due to the low $\mathrm{Fe}^{2+}$ oxidation rate, the latter being a pure chemical process. It is worth mentioning that the reoxidation of ferrous iron is catalyzed between $10^{5}$ and $10^{6}$ times by microorganisms (Ozkaya et al., 2007). It could also be inferred that the observed Eh and copper extraction trends could be related to the lag phase taking place in the batch experiments. Ilyas et al. (2013) showed that after a lag phase period of six days adapted Sulfobacillus strain was able to sustain up to $20.0 \mathrm{~g} / \mathrm{L}$ (optimum concentration $10.0 \mathrm{~g} / \mathrm{L})$ of ground PCB $(50-150 \mu \mathrm{m})$. As seen in Fig. 9(a), a satisfactory extraction within a short lag phase was achieved in our case using $20 \mathrm{~mm}$-long PCB fragments at solid concentration of $25.0 \mathrm{~g} / \mathrm{L}$. This approach enables to work with coarse particles while achieving copper extractions similar to the values reported in the literature for pulverized PCB (Table 1).

The evolution of both $\mathrm{pH}$ and acid consumption was also monitored. The results depicted in Fig. 11(a) suggest that the bio-leaching of PCB was accompanied by an increase in $\mathrm{pH}$ during the first two days of experiment, after which the $\mathrm{pH}$ stabilized below 2 in all inoculated tests. Similar findings were reported during column bioleaching of ground PCB $(-8 \mathrm{~mm}+3 \mathrm{~mm})$ (Ilyas et al., 2013). According to Brandl et al.(2001), pH increases mainly because of the presence of alkaline components in the PCB particularly in the non-metallic fractions. Notwithstanding, a $\mathrm{pH}$ decrease was
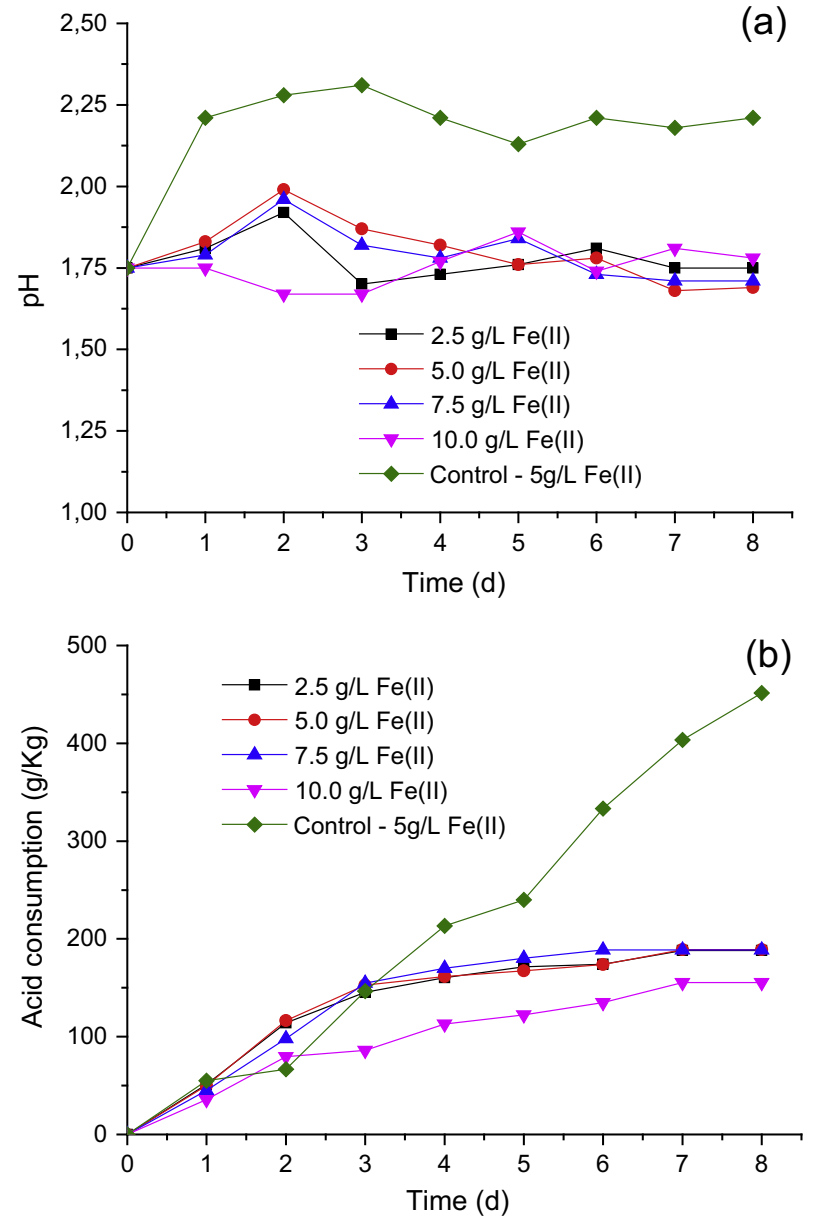

Fig. 11. Evolution of $\mathrm{pH}$ (a) and acid consumption (b) in rotating drum reactor Experimental conditions: $50^{\circ} \mathrm{C}$, pulp density $25.0 \mathrm{~g} / \mathrm{L}, \mathrm{pH} 1.75,80 \mathrm{~min}^{-1}$.
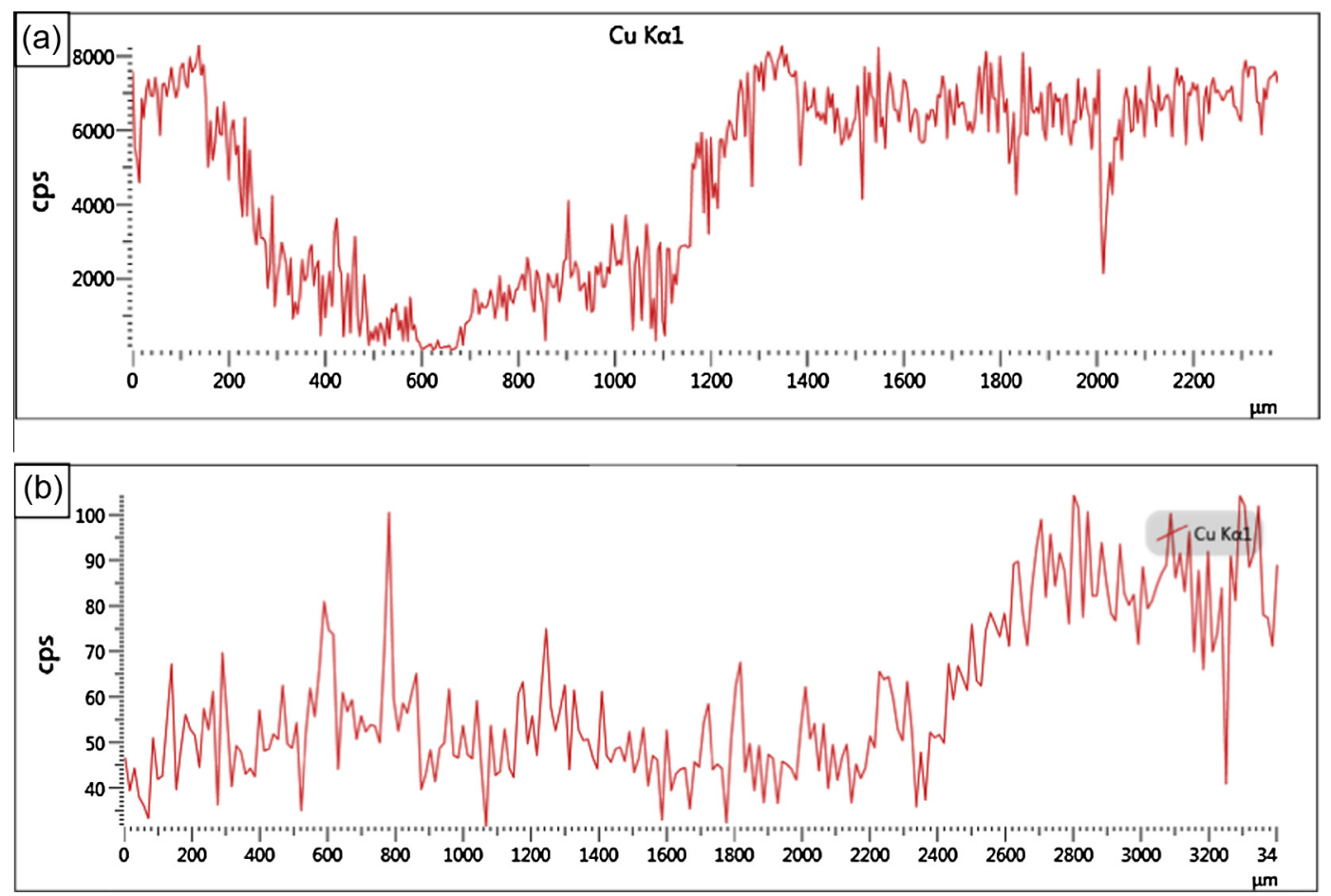

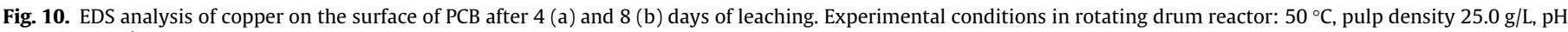
$1.75,80 \mathrm{~min}^{-1}$. 
noticed from the third day onwards which further stabilized around 1.75 - Fig. 11(a). Jarosite precipitation was observed for all $\mathrm{Fe}^{2+}$ concentrations tested, particularly at $10.0 \mathrm{~g} / \mathrm{L}$ and accounted for the low pH recorded under this condition (Fig. 6).

The experimental conditions in the rotating-drum reactor enabled an accurate determination of acid consumption during bioleaching. Addition of sulfuric acid was required to keep $\mathrm{pH}$ within the targeted value of $1.75 \pm 0.05$ and resulted in an acid consumption ranging from $155 \mathrm{~g} \mathrm{H}_{2} \mathrm{SO}_{4} / \mathrm{kg}$ (for $10.0 \mathrm{~g} / \mathrm{L}$ ferrous iron) to $451 \mathrm{~g} \mathrm{H}_{2} \mathrm{SO}_{4} / \mathrm{kg} \mathrm{PCB}$ (for the non-inoculated experiment) - Fig. 11(b). The lowest acid consumption was observed for the inoculated experiment carried out with $10.0 \mathrm{~g} / \mathrm{L}$ ferrous iron concomitantly to important jarosite and acid production. An acid consumption of $188 \mathrm{~g} \mathrm{H}_{2} \mathrm{SO}_{4} / \mathrm{kg} \mathrm{PCB}$ was calculated for the tests performed in the $2.5-7.5 \mathrm{~g} / \mathrm{L} \mathrm{Fe}^{2+}$ range. It should be recalled that results in Fig. 9(a) indicated that the fastest copper leaching rate was observed during the first four days - and that over that period a larger amount of sulfuric acid was added to maintain $\mathrm{pH}$ at its optimal value - Fig. 11(b). Studies done elsewhere (Bas et al., 2013), indicate that during experiments carried out at pH 1.7 using ground $(-250 \mu \mathrm{m})$ PCB and mixed mesophile strains an acid consumption of $550 \mathrm{~g} \mathrm{H}_{2} \mathrm{SO}_{4} / \mathrm{kg} \mathrm{PCB}$ was observed.

The technology proposed herein would be best suited for either small scale operations or residues with low copper content. As bioleaching has been industrially applied to the processing of refractory gold ores (gold locked inside pyrite grains) and copper sulfides the scale-up of such a biotechnology is feasible and a cost effective industrial application is forecasted. Nevertheless, future work is required to address such issues. Another interesting aspect would be to investigate the potential of using bioelectrochemistry to recovery copper from the solution purification.

\section{Conclusions}

When finely ground PCB $(-208 \mu \mathrm{m}+147 \mu \mathrm{m})$ were bioleached in shake-flask mode in the presence of $10.0 \mathrm{~g} / \mathrm{L}$ initial ferrous iron it was possible to leach within six days $94 \%$ and $99 \%$ of copper at $30{ }^{\circ} \mathrm{C}$ and $50^{\circ} \mathrm{C}$ using mesophilic and moderate thermophile cultures respectively, however at low solids density $(10.0 \mathrm{~g} / \mathrm{L})$. Substantial jarosite precipitation was observed under these conditions but without negatively affecting copper dissolution. Copper extraction increased concomitantly with the initial ferrous iron concentration only during the first two days. For the entire leaching duration however $5.0 \mathrm{~g} / \mathrm{L}$ has been established as an optimal concentration. When coarser PCB $(20 \mathrm{~mm})$ were bioleached in shake flasks at $50{ }^{\circ} \mathrm{C}$ and initial ferrous iron concentration kept at $5.0 \mathrm{~g} / \mathrm{L}$ it was possible to increase pulp solids density up to $25.0 \mathrm{~g} / \mathrm{L}$. Under these conditions and when PCB were subjected to a pre-weakening step (via jaw crusher) followed by lacquer coating removal nearly 76\% copper was extracted of eight days also suggesting a limited release of inhibiting elements in solution. Bioleaching with moderate thermophiles at $50^{\circ} \mathrm{C}$ and $5.0 \mathrm{~g} / \mathrm{L}$ ferrous iron concentration has enabled faster copper extraction than the one at $30^{\circ} \mathrm{C}$, but care should be exercised if the solution potential is chosen to monitor bacterial growth since the available metallic copper rapidly reduces ferric iron to its divalent state. Leaching of coarse PCB (being pre-weakened and having lacquer coating removed before leaching) inside an aerated rotating-drum reactor has been found more efficient than leaching in shakeflasks. The maximum degree of copper extraction (85\%) was reached after eight days for the bio-assisted test compared to $44 \%$ for the abiotic one. Also, acid consumption was more than two times lower for the biotic leaching than the abiotic one at the same initial concentration of ferrous iron $-5.0 \mathrm{~g} / \mathrm{L}$. The results are suggesting that bioleaching appears as a promising approach for processing PCB derived from electronic waste and could be integrated into a global copper recycling process from such sources. Further studies however are needed to confirm the approach feasibility and to enable higher than the tested degree of solids loading.

\section{Acknowledgements}

The authors wish to acknowledge the funding from CAPESBrazil and WBI-Belgium for the bilateral cooperative Project under which the presented research has been carried out. The Brazilian authors are also grateful to the funding agencies CNPq, FAPEMIG and FINEP.

\section{References}

Azevedo, R.D.A., 2008. Caracterização da diversidade microbiana em biorreatores de biolixiviação de Zinco. Ouro Preto. Universidade Federal de Ouro Preto. Trabalho de conclusão Thesis. Departament of Departamento de Ciências Biológicas, pp. 42.

Bas, A.D., Deveci, H., Yazici, E.Y., 2013. Bioleaching of copper from low grade scrap TV circuit boards using mesophilic bacteria. Hydrometallurgy 138 (0), 65-70.

Bhatti, T.M., Vuorinen, A., Tuovinen, O.H., 2012. Dissolution of non-sulfide phases during the chemical and bacterial leaching of a sulfidic black schist. Hydrometallurgy 117-118 (0), 32-35.

Brandl, H., Bosshard, R., Wegmann, M., 2001. Computer-munching microbes: metal leaching from electronic scrap by bacteria and fungi. Hydrometallurgy 59 (2-3), 319-326.

Crundwell, F.K., 2003. How do bacteria interact with minerals? Hydrometallurgy 71 (1-2), 75-81.

Cui, J., Zhang, L., 2008. Metallurgical recovery of metals from electronic waste: a review. J. Hazard. Mater. 158 (2-3), 228-256.

Dang, Z.-M., Yu, Y.-F., Xu, H.-P., Bai, J., 2008. Study on microstructure and dielectric property of the $\mathrm{BaTiO}_{3} /$ epoxy resin composites. Compos. Sci. Technol. 68 (1), $171-177$.

Daoud, J., Karamanev, D., 2006. Formation of jarosite during $\mathrm{Fe}^{2+}$ oxidation by Acidithiobacillus ferrooxidans. Min. Eng. 19 (9), 960-967.

Dopson, M., Halinen, A.-K., Rahunen, N., Boström, D., Sundkvist, J.-E., RiekkolaVanhanen, M., Kaksonen, A.H., Puhakka, J.A., 2008. Silicate mineral dissolution during heap bioleaching. Biotechnol. Bioeng. 99 (4), 811-820.

Dopson, M., Lövgren, L., Boström, D., 2009. Silicate mineral dissolution in the presence of acidophilic microorganisms: implications for heap bioleaching. Hydrometallurgy 96 (4), 288-293.

Ilyas, S., Anwar, M.A., Niazi, S.B., Ghauri, M.A., 2007. Bioleaching of metals from electronic scrap by moderately thermophilic acidophilic bacteria. Hydrometallurgy 88 (1-4), 180-188.

Ilyas, S., Lee, J.-C., Chi, R.-A., 2013. Bioleaching of metals from electronic scrap and its potential for commercial exploitation. Hydrometallurgy 131-132 (0), 138143.

Ilyas, S., Lee, J.-C., Kim, B.-S., 2014. Bioremoval of heavy metals from recycling industry electronic waste by a consortium of moderate thermophiles: process development and optimization. J. Cleaner Prod. 70 (0), 194-202.

Ilyas, S., Ruan, C., Bhatti, H.N., Ghauri, M.A., Anwar, M.A., 2010. Column bioleaching of metals from electronic scrap. Hydrometallurgy 101 (3-4), 135-140.

Jin, J., Shi, S.-Y., Liu, G.-1., Zhang, Q.-H., Cong, W., 2013. Comparison of Fe ${ }^{2+}$ oxidation by Acidithiobacillus ferrooxidans in rotating-drum and stirred-tank reactors. Trans. Nonferrous Met. Soc. China 23 (3), 804-811.

Lee, J.-C., Pandey, B.D., 2012. Bio-processing of solid wastes and secondary resources for metal extraction - a review. Waste Manage. 32 (1), 3-18.

Liu, G., Yin, J., Cong, W., 2007. Effect of fluid shear and particles collision on the oxidation of ferrous iron by Acidithiobacillus ferrooxidans. Min. Eng. 20 (13), 1227-1231.

Ozkaya, B., Sahinkaya, E., Nurmi, P., Kaksonen, A.H., Puhakka, J.A., 2007. Iron oxidation and precipitation in a simulated heap leaching solution in a Leptospirillum ferriphilum dominated biofilm reactor. Hydrometallurgy 88 (14), 67-74.

Pant, D., Joshi, D., Upreti, M.K., Kotnala, R.K., 2012. Chemical and biological extraction of metals present in E waste: a hybrid technology. Waste Manage. 32 (5), 979-990.

Petersen, J., Dixon, D.G., 2007a. Modelling zinc heap bioleaching. Hydrometallurgy 85 (2-4), 127-143.

Petersen, J., Dixon, D.G., 2007b. Principles, mechanisms and dynamics of chalcocite heap bioleaching. In: Donati, E.R., Sand, W. (Eds.), Microbial Processing of Metal Sulfides. Springer, Dordrecht, The Netherlands, pp. 193-218.

Pina, P.S., 2006. Estudo da biolixiviação e a da lixiviação química de um concentrado sulfetado de zinco. Ouro Preto, MG, Brazil. Universidade Federal de Ouro Preto. Estudo da biolixiviação e a da lixiviação química de um concentrado sulfetado de zinco Thesis. Departament of Rede Temática em Engenharia de Materiais REDEMAT, 79pp.

Poulin, R., Lawrence, R.W., 1996. Economic and environmental niches of biohydrometallurgy. Min. Eng. 9 (8), 799-810.

Schippers, A., 2007. Microorganisms involved in bioleaching and nucleic acid-based molecular methods for their identification and quantification. In: Donati, E.R., 
Sand (Eds.), Microbial Processing of Metal Sulfides. Springer Verlag: 3-33, Dordrecht.

Tuncuk, A., Stazi, V., Akcil, A., Yazici, E.Y., Deveci, H., 2012. Aqueous metal recovery techniques from e-scrap: Hydrometallurgy in recycling. Min. Eng. 25, 28-37.

van Hille, R.P., van Zyl, A.W., Spurr, N.R.L., Harrison, S.T.L., 2010. Investigating heap bioleaching: effect of feed iron concentration on bioleaching performance. Min. Eng. 23 (6), 518-525.

Watling, H.R., 2006. The bioleaching of sulphide minerals with emphasis on copper sulphides - a review. Hydrometallurgy 84 (1-2), 81-108.

Watling, H.R., Perrot, F.A., Shiers, D.W., 2008. Comparison of selected characteristics of Sulfobacillus species and review of their occurrence in acidic and bioleaching environments. Hydrometallurgy 93 (1-2), 57-65.
Xiang, Y., Wu, P., Zhu, N., Zhang, T., Liu, W., Wu, J., Li, P., 2010. Bioleaching of copper from waste printed circuit boards by bacterial consortium enriched from acid mine drainage. J. Hazard. Mater. 184 (1-3), 812-818.

Yang, T., Xu, Z., Wen, J., Yang, L., 2009. Factors influencing bioleaching copper from waste printed circuit boards by Acidithiobacillus ferrooxidans. Hydrometallurgy 97 (1-2), 29-32.

Zhu, N., Xiang, Y., Zhang, T., Wu, P., Dang, Z., Li, P., Wu, J., 2011. Bioleaching of meta concentrates of waste printed circuit boards by mixed culture of acidophilic bacteria. J. Hazard. Mater. 192 (2), 614-619.

Zhu, P., Chen, Y., Wang, L.Y., Zhou, M., Zhou, J., 2013. The separation of waste printed circuit board by dissolving bromine epoxy resin using organic solvent. Waste Manage. 33 (2), 484-488. 